\title{
Bycatch species composition over time by tuna purse- seine fishery in the eastern tropical Atlantic Ocean
}

\author{
Edgar Torres-Irineo • Monin Justin Amandè • Daniel Gaertner • \\ Alicia Delgado de Molina $\cdot$ Hilario Murua $\cdot$ Pierre Chavance $\cdot$ \\ Javier Ariz • Jon Ruiz • Nerea Lezama-Ochoa
}

Received: 27 August 2013/Revised: 13 February 2014/Accepted: 15 February 2014

(C) Springer Science+Business Media Dordrecht 2014

\begin{abstract}
Within the Ecosystem-based fisheries management framework, we evaluated the changes over time in bycatch species of the European tuna purse-seine fishery operating in the eastern Atlantic Ocean. Bycatch data was collected during two scientific observer programs conducted in the late 1990s and in the late 2000s. Over these two time periods, we compared the temporal trends in bycatch species composition, the probability of occurrence of functional groups per fishing set, the spatio-temporal species richness and the potential impact on several species listed in the red list of the International Union for Conservation of Nature (IUCN). The analyses were performed separately on the two main fishing modes of the fleet, i.e. sets on free-swimming school sets and on fish aggregating devices (FADs). Owing data quality constraints, we did not estimate bycatch rates. Ours results showed that the species composition of sharks caught on FADs decreased over time. The total species richness was higher for FAD sets than for free-swimming school sets (87 vs. 61 species respectively), such difference is common between fishing modes worldwide.
\end{abstract}

Communicated by David L. Hawksworth.

E. Torres-Irineo · M. J. Amandè · D. Gaertner · P. Chavance

UMR 212 EME, IRD Centre de Recherche Halieutique Méditerranéenne et Tropicale, Avenue Jean

Monnet, BP 171, 34200 Sète, France

E. Torres-Irineo $(\bowtie)$

Centro de Investigación y de Estudios Avanzados del Instituto Politécnico Nacional, Unidad Mérida.

Km 6 Antigua Carretera a Progreso Cordemex, 97310 Mérida, Yucatán, Mexico

e-mail: edgar.torres@mda.cinvestav.mx

M. J. Amandè

Département Ressources Aquatiques Vivantes, Centre de Recherches Océanologiques, 29, rue des Pêcheurs-BP V 18, Abidjan, Côte d'Ivoire

A. D. de Molina · J. Ariz

Instituto Español de Oceanografía, Apdo. Correos 1373, 38080 S/C Tenerife, Canary Island, Spain

H. Murua $\cdot$ J. Ruiz $\cdot$ N. Lezama-Ochoa

AZTI Tecnalia, Herrera Kaia, Portualde z/g, 20110, Pasaia, Gipuzkoa, Spain 
For the species catalogued as threatened by the IUCN, in free-swimming schools, $25.5 \%$ of the species caught during first period increased to $30.4 \%$ during second period, while for FAD-fishing the increase was from $28.8 \%$ during first period to $34.9 \%$ in second period. Ours findings suggest that tropical tuna purse-seine fisheries should include ecosystem-based governance of bycatch. Effective tuna management will require a combination of technological improvements for mitigating incidental catch of vulnerable species, best use of byproduct species, regulations in fishing practices and in spatial distribution of fishing effort, and international agreements that, together, can monitor and manage bycatch, reducing the negative fishing effects on the epipelagic ecosystem biodiversity.

Keywords Bycatch - Tropical tuna $\cdot$ Purse-seine fishing $\cdot$ Eastern tropical Atlantic $\cdot$ Ecosystem-based fisheries management

\section{Introduction}

Fisheries exploitation affects not only target species populations but can also affect the fish community structure and diversity by removing non-target species through bycatch (i.e. the incidental catch of undersized classes of the target species and other non-target species; (Davies et al. 2009), changing the total biomass, species composition, and predator-prey relationships. Bycatch species caught are either discarded when species have not economic value or due to regulatory measures, or retained on board as byproduct when non-target species have high market value, and landed in local markets (Hall 1996; Romagny et al. 2000).

In addition to the long-term sustainability of fishing stocks, managing and mitigating bycatch has been the most pressing issue facing the commercial fishing industry worldwide in recent years (Hall and Mainprize 2005). Bycatch is also a major concern to conservation bodies (both governmental and nongovernmental) and the wider public (Alverson et al. 1994; Hall and Mainprize 2005; Gilman et al. 2013). This practice is considered to be responsible for economic loss and have ecological effects on keystone species which are important for ecosystem performance and structure (Alverson et al. 1994; Garcia et al. 2003). Vulnerable species groups subject to bycatch include many taxa such as seabirds, sea turtles, marine mammals, elasmobranchs and other bony fish species. Many of these species are particularly vulnerable to overexploitation and can decline over short time scales (decades or less). Evaluating how bycatch impacts the epipelagic ecosystem is difficult, since pelagic populations are fundamentally difficult to monitor, including species with a terrestrial component to their life cycle (e.g., sea turtles and seabirds that nest on land; (Lewison et al. 2004). However, given the demographic vulnerability of long-lived species, the incidental catch of only a few individuals can have serious population-level effects.

The Atlantic tropical tuna purse-seine fishery is a multispecies fishery targeting yellowfin (Thunnus albacares), and skipjack (Katsuwonus pelamis), and incidentally bigeye (T. obesus). For the last decade, the catch of tunas reported by the EU (France and Spain) tuna purse-seiners varied between 60,000 and 85,000 t/year (Pianet et al. 2011), contributing between 21 and $28 \%$ of the total tropical tuna catch in the eastern Atlantic. Tuna schools are detected visually by clues at the sea surface during daylight. The predominant sighting clues reported in logbooks are (1) free-swimming schools (also termed non- 
Table 1 Summary of observer data collected during both time periods considered

\begin{tabular}{llllll}
\hline Observer program & Time period & Observed fishing trips & FS $^{\mathrm{a}}$ sets & FAD sets & Coverage rate \\
\hline EU Bigeye & $1997-1999$ & 51 & 787 & 451 & $8.70 \%$ \\
DCF & $2005-2008$ & 35 & 409 & 345 & $3.80 \%$ \\
\hline
\end{tabular}

${ }^{\mathrm{a}}$ Free-swimming schools. ${ }^{\mathrm{b}}$ FAD refers to both natural and artificial objects

associated schools) related to bird flocks and/or when the water surface is rippled, as if a breeze were blowing over it, and (2) floating objects, such as fish aggregating devices (FADs), due to the aggregation behavior of tropical tuna with these objects. The setting operations associated with these two sighting indices define the fishing modes: freeswimming school sets and FADs sets (or FAD-fishing), respectively. Some sets are performed on whales and whale-sharks, but owing to the tuna species composition and size of the fish in the catch they are classified as free-swimming schools sets and FADs sets, respectively (Pallarés and Petit 1998).

Both fishing modes produce bycatch to a different extent and have a different species composition. FAD-fishing bycatch is considerably greater than that obtained from fishing on free-swimming schools ( $15 \mathrm{t} / 100 \mathrm{t}$ and $2.8 \mathrm{t} / 100 \mathrm{t}$ of tuna landed, respectively; (Amandè et al. 2010). The increasing use of FADs since the early 1990s has generated concern about their effects on the epipelagic ecosystem, and has become a management and conservation issue for the International Commission for the Conservation of Atlantic Tunas (ICCAT). The tropical tuna purse-seine fishery occasionally captures sea turtles (Amandè et al. 2010), billfishes (Gaertner et al. 2002), and sharks, mainly the silky shark (Carcharhinus falciformis), comprising up to $90 \%$ of the shark bycatch, and the oceanic white tip (C. longimanus) (Hall et al. 2000; Amandè et al. 2008). However, there are no studies concerning the effects of tuna purse-seine fishing modes on species composition over time and there is uncertainty about the total number of species that may be caught by these fishing modes.

This study focuses on the potential effects over time of the EU fleet on the bycatch assemblage by fishing mode. With this consideration in mind our purpose is threefold: first we analyze the variability in bycatch species composition. Second, we compare and estimate the species richness of the bycatch. Third, we investigate the spatial occurrence of the bycatch species which are currently listed in the Red List of Threatened Species of the International Union for Conservation of Nature (IUCN).

\section{Materials and methods}

Data

We compared bycatch data collected by onboard observers on EU purse-seiners operating in the eastern Atlantic Ocean in two different periods. The first period was covered by an observer program under the "EU Research Bigeye Program" (Reg. 96/028) conducted from mid-1997 to mid-1999, targeting bigeye tuna (Ariz and Gaertner 1999) and characterize the period of full development of FAD-fishing. The second period corresponds to the EU "Data Collection Framework DCF" (Reg. 1543/2000 and 199/2008) between 2005 and 2008, targeting the whole purse seine bycatch species (see Table 1 for statistics of the sampling effort). 
Observers onboard identified whenever possible species caught after every fishing set. Owing to time constraints during the setting process, in some circumstances certain bycatch species may not have been correctly identified or may have been classified as genus or family level. Furthermore, observers reported bycatch species in numbers of individuals (whenever the number of individuals was moderate) and average length or weight in each fishing set, or in opposite estimated total weights of each bycatch species when marine animals were too numerous. For the analysis, we decided to use presence/absence data instead of numbers because during EU Bigeye program, the objective addressed the effects of FADs on juvenile bigeye tuna, thus less attention was paid on bycatch species. Consequently, the accuracy of numbers of individuals or total weight of bycatch species might be misled. Notice however that this issue was corrected during the DCF program, which focuses in overall species caught by tuna purse-seiners. With these considerations in mind we used a presence/absence criterion for comparing the changes over time of several functional groups (small tuna species, billfishes, sharks, rays, turtles and other bony fishes; Table 2).

Analyzing the bycatch species composition by fishing mode

Assuming that variability in species composition among sampling units within a given spatial or temporal scale may be defined as $\beta$ diversity (Anderson et al. 2006), changes in species composition over the two time periods was evaluated on a dissimilarity-based test for homogeneity of multivariate dispersions (PERMDISP; Anderson 2006). Unlike the traditional likelihood-based test for differences in multivariate dispersions, the PERMDISP test is not sensitive to the lack of normality in the data and allows the use of any multivariate measure based on pairwise resemblances among sample units (e.g., among fishing trips). We used the Euclidean distance on presence/absence data, since this distance is assumed to provide high resolution for measuring changes in communities where many species are either rare or narrowly distributed (Anderson et al. 2011). For this analysis the fishing trip was selected as the unit sample to carry out the analyses but we accounted for the fact that a vessel may perform both fishing modes along a fishing trip by combining the fishing trip and the fishing mode in a new categorical variable, where species caught in each fishing trip were divided into species caught on free-swimming schools sets and FADs sets. The PERMDISP test was carried out by applying one-way ANOVA to the Euclidean distances from unit samples (fishing trips) within a given time period (corresponding to EU Bigeye or DCF observer programs respectively) to their group median (centroid), as follows:

$$
z_{i j}^{m}=\Delta\left(x_{i j}, m_{i}\right),
$$

where, $x_{i j}$ is the vector which denotes the $j$ th observation in the $i$ th time period in the multivariate space of the $p$ variables (species). Therefore, the greater the distance is to the centroid, the greater the variability is in species composition among samples.

Because of potential misidentification at the species level, particularly during the EU Bigeye program, PERMDISP test was conducted at the family level. It should be stressed that differences in multivariate dispersions at species level are maintained up to families (Terlizzi et al. 2009). We used only occurrences when individuals were identified to species level in order to corroborate family results. This first analysis provides an overall picture of the variability in species composition by fishing mode between both time periods. However, this may hide changes in species composition by functional groups (e.g., 
Table 2 List of functional groups and species reported by observers during EU Bigeye and DCF programs

\begin{tabular}{|c|c|c|c|c|c|c|}
\hline \multirow[t]{2}{*}{ Functional groups } & \multirow[t]{2}{*}{ Species } & \multicolumn{2}{|c|}{$\begin{array}{l}\text { Free-swimming } \\
\text { school }\end{array}$} & \multicolumn{2}{|c|}{$\begin{array}{l}\text { FAD-associated } \\
\text { school }\end{array}$} & \multirow[t]{2}{*}{ IUCN Status } \\
\hline & & $\begin{array}{l}\text { EU } \\
\text { Bigeye }\end{array}$ & DCF & $\begin{array}{l}\text { EU } \\
\text { Bigeye }\end{array}$ & DCF & \\
\hline \multirow[t]{11}{*}{ Sharks } & Carcharhinidae sp. & 1 & 0 & 19 & 7 & - \\
\hline & Carcharhinus falciformis & 32 & 1 & 65 & 53 & Near threatened \\
\hline & Carcharhinus longimanus & 4 & 2 & 13 & 4 & Vulnerable \\
\hline & Carcharodon carcharias & 1 & 0 & 1 & 0 & Vulnerable \\
\hline & Isurus oxyrinchus & 3 & 4 & 4 & 4 & Vulnerable \\
\hline & Lamniformes & 1 & 0 & 1 & 0 & - \\
\hline & Prionace glauca & 2 & 0 & 3 & 0 & Near threatened \\
\hline & Sphyrna lewini & 16 & 4 & 6 & 0 & Endangered \\
\hline & Sphyrna mokarran & - & - & 1 & 0 & Endangered \\
\hline & Sphyrna zygaena & 27 & 7 & 9 & 3 & Vulnerable \\
\hline & Sphyrnidae & 32 & 0 & 7 & 0 & - \\
\hline \multirow[t]{7}{*}{ Rays } & Dasyatidae & 4 & 0 & 1 & 0 & - \\
\hline & Pteroplatytrygon violacea & 15 & 6 & 3 & 1 & Least concern \\
\hline & Manta birostris & 16 & 2 & 4 & 4 & Vulnerable \\
\hline & Mobula coilloti & 0 & 2 & 0 & 1 & Unknown \\
\hline & Mobula mobular & 22 & 4 & 2 & 1 & Endangered \\
\hline & Mobula rancurelli & 0 & 3 & 1 & 2 & Unknown \\
\hline & Mobula tarapacana & 26 & 0 & 6 & 0 & Data deficient \\
\hline \multirow[t]{8}{*}{ Billfish } & Istiophoridae & 11 & 0 & 20 & 3 & - \\
\hline & Istiophorus albicans & 99 & 79 & 22 & 19 & Unknown \\
\hline & Makaira indica & 2 & 1 & 7 & 6 & Data deficient \\
\hline & Makaira nigricans & 23 & 17 & 80 & 66 & Vulnerable \\
\hline & Tetrapterus albidus & 3 & 1 & 2 & 2 & Vulnerable \\
\hline & Tetrapturus angustirostris & 0 & 1 & 0 & 1 & Data deficient \\
\hline & Tetrapturus pfluegeri & 3 & 0 & 1 & 0 & Least concern \\
\hline & Xiphias gladius & 2 & 0 & 7 & 2 & Least concern \\
\hline \multirow[t]{7}{*}{ Turtles } & Caretta caretta & 14 & 2 & 11 & 1 & Endangered \\
\hline & Chelonia mydas & 1 & 6 & 2 & 2 & Endangered \\
\hline & Dermochelys coriacea & 12 & 2 & 3 & 1 & $\begin{array}{l}\text { Critically } \\
\text { endangered }\end{array}$ \\
\hline & Eretmochelys imbricata & 1 & 1 & 1 & 0 & $\begin{array}{l}\text { Critically } \\
\text { endangered }\end{array}$ \\
\hline & Lepidochelys kempii & 3 & 3 & 4 & 2 & $\begin{array}{l}\text { Critically } \\
\text { endangered }\end{array}$ \\
\hline & Lepidochelys olivacea & 0 & 7 & 5 & 5 & Vulnerable \\
\hline & Unidentified turtle & 3 & 1 & 10 & 0 & - \\
\hline \multirow{4}{*}{$\begin{array}{l}\text { Small tuna } \\
\text { species }\end{array}$} & Auxis rochei & 19 & 11 & 16 & 29 & Least concern \\
\hline & Auxis sp. & 21 & 0 & 52 & 0 & - \\
\hline & Auxis thazard & 59 & 6 & 41 & 35 & Least concern \\
\hline & Euthynnus alletteratus & 12 & 2 & 18 & 21 & Least concern \\
\hline
\end{tabular}


Table 2 continued

\begin{tabular}{|c|c|c|c|c|c|c|}
\hline \multirow[t]{2}{*}{ Functional groups } & \multirow[t]{2}{*}{ Species } & \multicolumn{2}{|c|}{$\begin{array}{l}\text { Free-swimming } \\
\text { school }\end{array}$} & \multicolumn{2}{|c|}{$\begin{array}{l}\text { FAD-associated } \\
\text { school }\end{array}$} & \multirow[t]{2}{*}{ IUCN Status } \\
\hline & & $\begin{array}{l}\text { EU } \\
\text { Bigeye }\end{array}$ & DCF & $\begin{array}{l}\text { EU } \\
\text { Bigeye }\end{array}$ & DCF & \\
\hline \multirow[t]{37}{*}{ Other bony fishes } & Abalistes stellatus & 2 & 0 & 8 & 0 & Not assessed \\
\hline & Acanthocybium solandri & 8 & 7 & 226 & 180 & Least concern \\
\hline & Aluterus monoceros & - & - & 2 & 44 & Not assessed \\
\hline & Aluterus scriptus & - & - & 0 & 1 & Not assessed \\
\hline & Balistes carolinensis & 0 & 2 & 36 & 72 & Not assessed \\
\hline & Balistes punctatus & 0 & 1 & 4 & 35 & Not assessed \\
\hline & Balistidae & 1 & 0 & 27 & 2 & - \\
\hline & Belonidae & - & - & 3 & 0 & - \\
\hline & Canthidermis maculata & 8 & 2 & 170 & 128 & Not assessed \\
\hline & Carangidae & - & - & 5 & 1 & - \\
\hline & Caranx crysos & 2 & 0 & 87 & 112 & Least concern \\
\hline & Caranx sexfasciatus & - & - & 0 & 1 & Least concern \\
\hline & Coryphaena equiselis & 2 & 1 & 50 & 6 & Least concern \\
\hline & Coryphaena hippurus & 15 & 4 & 165 & 109 & Least concern \\
\hline & Coryphaenidae & 3 & 0 & 39 & 0 & - \\
\hline & Diodon hystrix & 14 & 6 & 15 & 4 & Not assessed \\
\hline & Diodontidae & 11 & 0 & & & - \\
\hline & Echeneidae & - & - & 1 & 2 & - \\
\hline & Elagatis bipinnulata & 10 & 6 & 199 & 211 & Not assessed \\
\hline & Exocoetidae & 2 & 0 & 7 & 0 & - \\
\hline & Gempylus serpens & 0 & 1 & & & Not assessed \\
\hline & Kyphosus sectatrix & 4 & 0 & 58 & 27 & Not assessed \\
\hline & Kyphosus sp. & - & - & 16 & 5 & - \\
\hline & $\begin{array}{l}\text { Lagocephalus } \\
\quad \text { lagocephalus }\end{array}$ & 0 & 2 & 0 & 1 & Not assessed \\
\hline & Lampris sp. & - & - & 1 & 0 & - \\
\hline & Lobotes surinamensis & 2 & 3 & 133 & 67 & Not assessed \\
\hline & Luvarus imperialis & 0 & 1 & - & - & Not assessed \\
\hline & Masturus lanceolatus & - & - & 3 & 1 & Not assessed \\
\hline & Mola mola & 73 & 17 & 12 & 4 & Not assessed \\
\hline & Molidae & 12 & 0 & 4 & 0 & - \\
\hline & Naucrates ductor & 3 & 3 & 3 & 0 & Not assessed \\
\hline & Ranzania laevis & 2 & 1 & - & - & Not assessed \\
\hline & Remora brachyptera & - & - & 0 & 2 & Least concern \\
\hline & Remora remora & 17 & 16 & 21 & 9 & Not assessed \\
\hline & Remorina albescens & 0 & 2 & & & Least concern \\
\hline & Ruvettus pretiosus & 0 & 2 & 0 & 24 & Not assessed \\
\hline & Sarda sarda & 3 & 0 & & & Least concern \\
\hline
\end{tabular}


Table 2 continued

\begin{tabular}{|c|c|c|c|c|c|c|}
\hline \multirow[t]{2}{*}{ Functional groups } & \multirow[t]{2}{*}{ Species } & \multicolumn{2}{|c|}{ Free-swimming school } & \multicolumn{2}{|c|}{ FAD-associated school } & \multirow[t]{2}{*}{ IUCN Status } \\
\hline & & EU Bigeye & DCF & EU Bigeye & DCF & \\
\hline & Scomber sp. & 0 & 2 & 0 & 1 & - \\
\hline & Scombridae & 1 & 0 & - & - & - \\
\hline & Seriola rivoliana & - & - & 5 & 14 & Not assessed \\
\hline & Serranidae & - & - & 3 & 0 & - \\
\hline & Sphyraena barracuda & 4 & 1 & 87 & 29 & Not assessed \\
\hline & Sphyraenidae & - & - & 7 & 0 & - \\
\hline & Uraspis secunda & 1 & 2 & 42 & 15 & Not assessed \\
\hline & Uraspis sp. & - & - & 0 & 2 & - \\
\hline & Uraspis uraspis & - & - & 0 & 3 & Not assessed \\
\hline
\end{tabular}

It is shown the number of sets in which the species occurred by fishing mode (free-swimming school and FADs) within each observer program as well as their IUCN status. It must be kept in mind that IUCN status concerns all fisheries and not specifically the consequences of the purse seiner activities

a decrease in the number of shark species may be compensated by an opposite trend in billfish species). Consequently, we performed PERMDISP by functional group using occurrences of individuals identified to species level. Additionally, we used quarterly strata to calculate the probability of occurrence by species groups per set $(P)$. The probability of occurrence per fishing mode was calculated as:

$$
P_{i j}=S_{i j} / S_{j}
$$

with $\left(S_{i j}\right)$ the numbers of sets for which species group $i$ was present and $\left(S_{j}\right)$ the total number of sets observed for stratum $j$.

Species richness

Estimating species richness of the tropical tuna purse-seine fishery is relevant because the ICCAT has listed around 242 bycatch species (http://www.iccat.int/en/bycatchspp.htm) which have been caught with all tuna fishing gears (i.e., longline, pole-and-line, and purseseine) in the Atlantic Ocean. In the case of the tropical purse seine fishery we are interested to investigate spatio-temporal changes in species richness and how many species can potentially be caught by the two main fishing modes. With the objective to describe the assemblage associated with each fishing mode, and to investigate whether there was any change between the two time periods, we used the overall number of species reported summing both periods, and then by functional groups. Billfishes and turtles were omitted since the total number of species of these groups inhabiting the Atlantic Ocean is assumed to be already known.

We used sample-based rarefaction curves to account for natural levels of sample heterogeneity (patchiness) in the data, (Gotelli and Colwell 2001). These curves were estimated in a quarterly basis to account for spatio-temporal distribution of purse-seine vessels. Rarefaction curves represent the plot of the cumulative number of species detected as a function of the number of samples, reach an asymptote as fewer new species are found per unit of new samples collected, giving insight about the expected species richness 
(Gotelli and Colwell 2001). Although this asymptote is rarely reached, it is possible to estimate the total species richness by extrapolation approaches (Colwell et al. 2004). Among the different species richness estimators, we used Chao2 (Chao 1984) because is known to provide a better estimate of true species richness than observed species richness, especially for small sample numbers (Colwell and Coddington 1994). This estimator is expressed as: $S_{o b s}+q_{1}^{2} / q_{1}^{2} 2 q_{2}$ where $S_{o b s}$ is the number of species observed, $q_{1}$ is the number of species that occur in only one sample and $q_{2}$ is the number of species that occur in exactly two samples. For this analysis, we gathered the total species reported in both periods considered to calculate the Chao 2 estimator.

\section{Bycatch species classified as threatened by IUCN}

In order to describe and locate which areas may be affected by the activities of the tropical tuna purse-seine fishery on the epipelagic ecosystem of the eastern Atlantic Ocean, we show the spatial occurrences by fishing mode of the incidental species which are also classified at least as vulnerable on the IUCN red list. We classified these species into functional groups again as early in this study. For instance, among the 6 shark species with high occurrence only the silky shark (C.falciformis), scalloped hammerhead (Sphyrna lewini), oceanic whitetip shark (C. longimanus), and smooth hammerhead (S. zygaena) are listed as near threatened, endangered, and vulnerable, which were considered and termed here within Sharks functional group. The same classification scheme was used for Rays, Billfishes, and Turtles.

\section{Results}

Impact of the fishing modes on the bycatch species composition over time

From the PERMDISP tests, there was no evidence of differences in the variability of species, or families, composition among fishing trips between the 2 periods analyzed, whatever the fishing mode (Table 3). Changes in species composition by functional groups showed similar patterns, except for the bycatch of sharks on FADs and for rays caught on free-swimming schools. For these two chondrichthyan groups, the species composition was larger (i.e. high average distance to centroid $\bar{d}_{c e n}$ ) during 1997-1999 than during 2005-2008. The average distance to the centroid also reflects how high, or low, the species composition among fishing trips is. For instance, when using all species in the calculation of the test, sets on FADs presented the highest value, indicating a greater diversity for this fishing mode compared to free-swimming school sets. Among each functional group, as expected, bony fishes presented the highest diversity for both fishing modes, while lowest values associated to rays and turtles caught on FADs, and small tuna species and turtles caught on free-swimming schools.

Probabilities of occurrence per set and by quarter showed marked differences between fishing modes (Fig. 1). FAD-fishing is characterized by a high probability of occurrence $(\sim 0.9)$ of other bony fishes, while fishing on free-swimming schools is characterized by billfishes and other bony fishes $(\sim 0.5)$. Sea turtles are the functional group least likely to occur per set $(<0.2)$. Between periods, during the first period (1997-1999), the probability of occurrence of all functional groups was similar throughout the second and third quarter. In contrast, during the second period (2005-2008) the highest probability of occurrence was observed for billfishes and other bony fishes. 
Table 3 Multivariate dispersion $\left(\bar{d}_{c e n}\right)$ based on the Euclidean distance of presence/absence by bycatch species groups for FAD-fishing and free-swimming schools, including results of the PERMDISP test, used for the comparison between EU Bigeye (1997-1999) and DCF observer (2005-2008) programs

\begin{tabular}{llllllll}
\hline & $\bar{d}_{\text {cen }}$ EU Bigeye & $\bar{d}_{c e n}$ DCF & df & Sum Sq & Mean Sq & $F$ & Pr $(>F)$ \\
\hline FADs & & & & & & & \\
All families & 1.745 & 1.72 & 1 & 0.0124 & 0.012369 & 0.0722 & 0.801 \\
All species & 2.435 & 2.376 & 1 & 0.0632 & 0.063172 & 0.5006 & 0.491 \\
Small tuna species & 0.7274 & 0.5617 & 1 & 0.5177 & 0.51773 & 1.7485 & 0.195 \\
Sharks & 0.8706 & 0.6864 & 1 & 0.6397 & 0.63974 & 4.6977 & 0.023 \\
Rays & 0.3049 & 0.2121 & 1 & 0.1622 & 0.16221 & 0.7887 & 0.376 \\
Billfish & 0.7347 & 0.7683 & 1 & 0.0213 & 0.021305 & 0.1438 & 0.712 \\
Turtles & 0.3764 & 0.3156 & 1 & 0.0697 & 0.06969 & 0.2552 & 0.573 \\
Other bony fishes & 1.788 & 1.843 & 1 & 0.0567 & 0.056675 & 0.8381 & 0.365 \\
Free-swimming schools & & & & & & & 0.124 \\
All families & 1.758 & 1.613 & 1 & 0.3874 & 0.38744 & 2.5428 & 0.124 \\
All species & 2.009 & 1.92 & 1 & 0.1452 & 0.1452 & 0.4737 & 0.522 \\
Small tuna species & 0.3843 & 0.2623 & 1 & 0.2931 & 0.29314 & 1.0911 & 0.309 \\
Sharks & 0.5958 & 0.371 & 1 & 0.9962 & 0.99623 & 2.7419 & 0.1 \\
Rays & 0.695 & 0.4493 & 1 & 1.19 & 1.19 & 4.4805 & 0.038 \\
Billfish & 0.7547 & 0.6552 & 1 & 0.1954 & 0.19539 & 1.4288 & 0.237 \\
Turtles & 0.4057 & 0.487 & 1 & 0.1304 & 0.13041 & 0.3996 & 0.506 \\
Other bony fishes & 1.196 & 1.114 & 1 & 0.1336 & 0.13356 & 0.3685 & 0.549 \\
\hline
\end{tabular}

Species richness over time

There was no evidence of a change in the number of species by fishing mode between time periods: 49 vs. 47 for FADs ( 451 vs. 345 sets), and 45 in both cases for free-swimming school (787 vs. 409 sets), respectively (Table 4). After gathering the observations collected during both periods, a total of 57 species were reported for FADs sets, and 56 species for free-swimming schools sets.

Chao2's estimates of the total species richness for each fishing mode suggest that for sets on FADs a maximum of 87 species can be caught by purse-seiners, while for freeswimming schools, 61 species can potentially be caught (Table 4). Based on the Chao2 estimator, with the exception of sharks caught on FADs, where the number of shark species could be up to 10 , there was no evidence that the number of species observed in functional groups be underestimated (Table 4). However, for sharks less species were observed during the second period than the first (Table 2).

The spatio-temporal results showed changes in species richness throughout the year for each fishing mode over the two periods analyzed and none of the rarefaction curves reached the asymptote. For free-swimming school sets the highest species richness was observed during second and third quarter (Fig. 2). The spatial distribution of these sets was near to the coast both, in the Gulf of Guinea and Senegal (Fig. 2). Over the EU Bigeye and DCF programs, the rarefaction curves growth slowly, suggesting that the bycatch species on free-swimming school sets are not systematically caught. However, the DCF rarefaction curves were above the EU Bigeye curves, suggesting an increase of bycatch species caught in free-swimming school sets. 


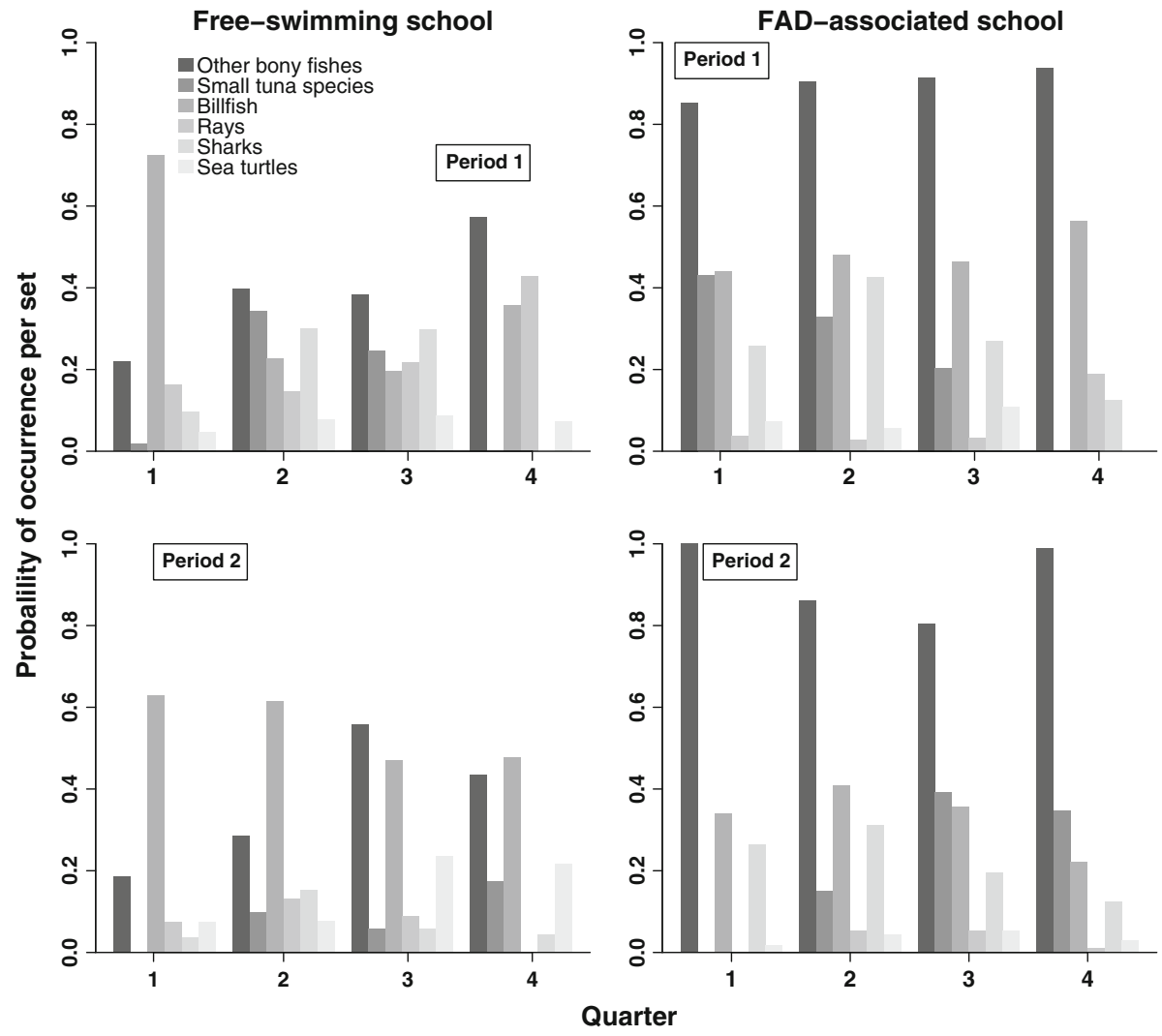

Fig. 1 Quarterly occurrence probability per set by species group for each fishing mode (Free-swimming school and FAD-associated school) during time period 1 (1997-1999), and 2 (2005-2008). Quarter: 1 January-March, 2 April-June, 3 July-September, 4 October-December

By contrast, for FAD sets, the highest number of species richness was observed during the first and third quarters (Fig. 3). Spatially, during these quarters, the purse seine fleet was distributed offshore, along the equator mainly (Fig. 3). Comparison between observer programs, during DCF period, fewer species were reported, but curves for both periods are overlapped, suggesting that the same number of species can be caught in recent years as during the late 1990s. Furthermore, the rarefaction curves growth rapidly for FAD sets, suggesting the high incidence of different species. Because none of the curves reached the asymptote, this suggests that for FADs sets there are species that may be caught yet or identified by increasing the number of fishing trips with observers.

Species listed as threatened on the IUCN red list

All the species present in the bycatch of the tropical purse seiners and listed on the IUCN Red List, were more frequently reported during the late 1990s than during the late 2000s (Table 2). Silky shark (an IUCN-near threatened species), which is mainly associated with FADs, was among the four shark species listed by the IUCN with the highest occurrence. In contrast to silky shark, scalloped hammerhead (IUCN-endangered) was more common 
Table 4 Species richness observed during each period and for the total combined, and estimated from the species richness asymptotes and the corresponding standard errors for the Chao 2 estimator

\begin{tabular}{lllllll}
\hline & Species EU Bigeye & Species DCF & Total & Chao2 & Chao2.se & $\mathrm{n}$ \\
\hline FADs & & & & & & \\
All species & 49 & 47 & 57 & 87.3 & 28.7 & 796 \\
Sharks & 8 & 4 & 8 & 10 & 3.7 & 796 \\
Rays & 5 & 5 & 6 & 6.5 & 1.3 & 796 \\
Other bony fishes & 21 & 24 & 27 & 27.0 & 0 & 796 \\
Free-swimming schools & 45 & 45 & 56 & 61.1 & 4.4 & 1,196 \\
All species & 7 & 5 & 7 & 7 & 0 & 1,196 \\
Sharks & 4 & 5 & 6 & 6 & 0 & 1,196 \\
Rays & 4 & 20 & 25 & 26.8 & 2.2 & 1,196 \\
Other bony fishes & 17 & & & &
\end{tabular}

\section{Free-swimming school sets}
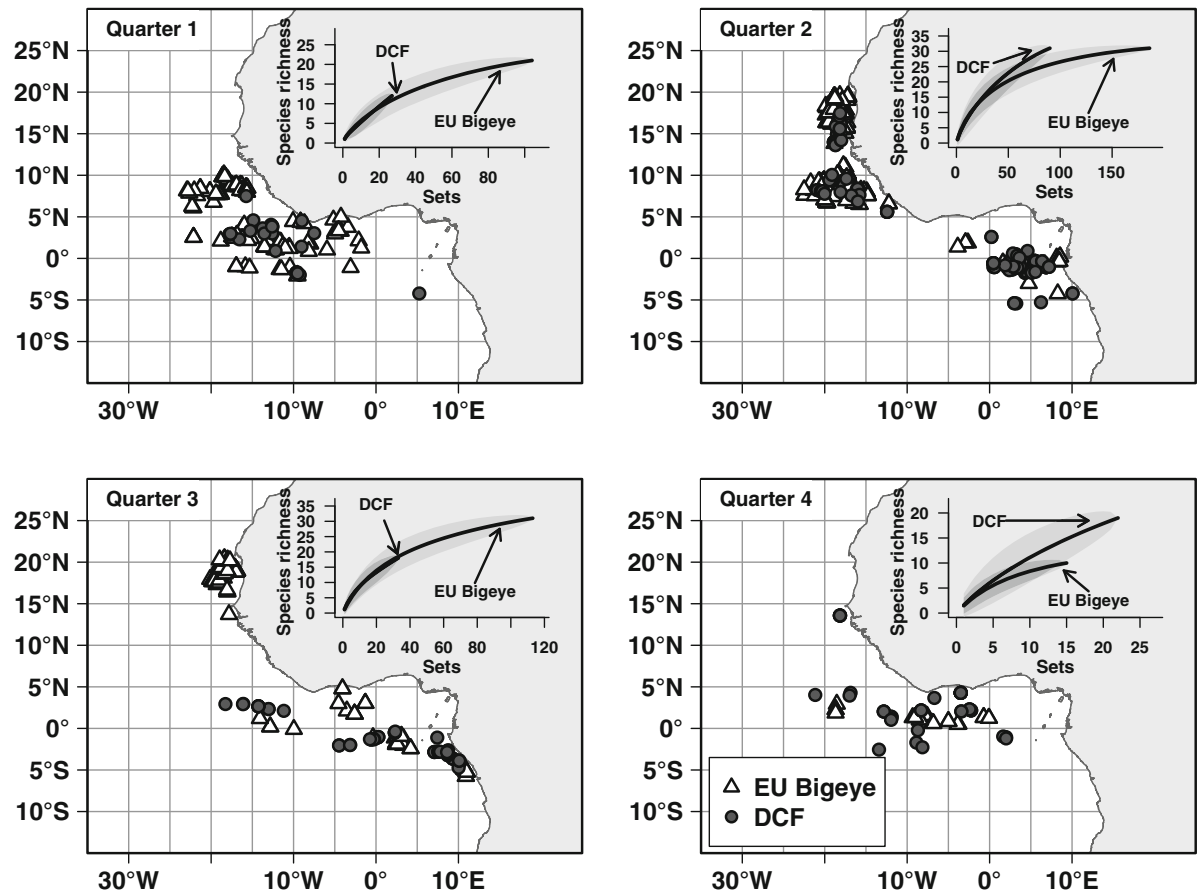

Fig. 2 Spatio-temporal distribution (quarterly) of free-swimming school sets sampled for EU Bigeye (white triangles) and DCF (dark grey dots) programs. For each quarter it is presented the species richness rarefaction curves for each observer program. Quarter: 1 January-March, 2 April-June, 3 July-September, 4 October-December

on free-swimming school sets during the first period. Atlantic sailfish (Istiophorus albicans) and Atlantic blue marlin (Makaira nigricans) were the main billfish species present in purse seine bycatch. The former species (whose status on the IUCN list is unknown) was 
FADs sets
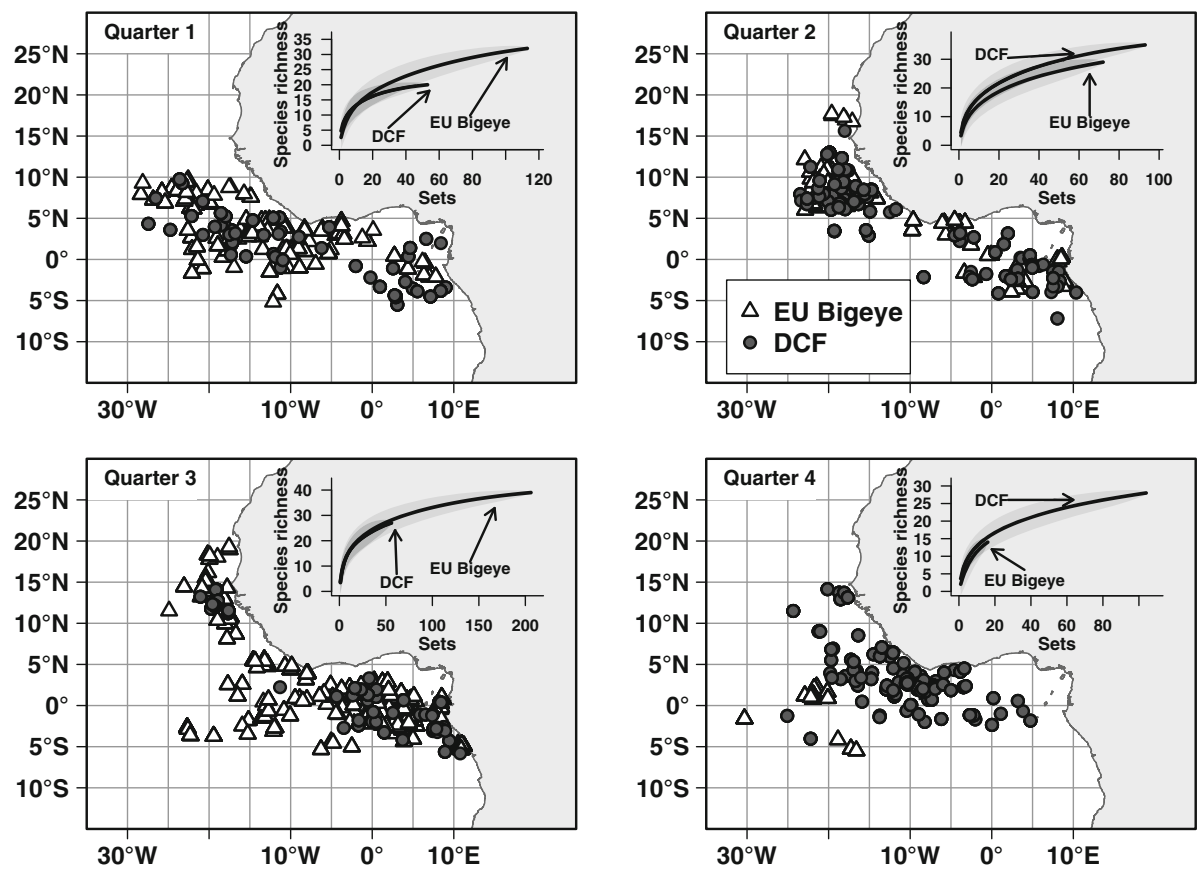

Fig. 3 Spatio-temporal distribution (quarterly) of FAD sets sampled for EU Bigeye (white triangles) and DCF (dark grey dots) programs. For each quarter it is presented the species richness rarefaction curves for each observer program. Quarter: 1 January-March, 2 April-June, 3 July-September, 4 October-December

more common in free-swimming schools than on FADs in contrast to the latter which is (listed as vulnerable by IUCN) and is more frequent on FADs than in free-swimming schools. Sharks and billfishes associated to FAD sets were caught mainly offshore, while the other functional groups were caught mainly inshore (Fig. 4).

In the group of rays, the giant manta (Manta birostris) and the devil fish (Mobula mobular) are listed by the IUCN as vulnerable and endangered respectively. Both species were present in purse-seine bycatch during both periods, but the highest occurrences were found in free-swimming schools sets during the first period (Table 2). Among the six species of sea turtles caught incidentally by purse-seiners, three are listed by IUCN as critically endangered, two endangered and one vulnerable. Occurrences of sea turtles were the least number of times and observers onboard reported that most of the individuals were released to the sea alive. However, these values may be biased since they do not include turtles that may have been entangled in the net hanging under the FAD.

As depicted by Fig. 4, bycatch of sharks on FADs were mainly in front of Liberia and near Gabon, while bycatch of free-swimming schools was inshore near to Liberia and Senegal. FADs and free-swimming school bycatch of ray species was mainly above $5^{\circ} \mathrm{N}$ latitude near to the African west coast. Atlantic blue marlin was caught along the equator to $25^{\circ} \mathrm{W}$ longitude and between the equator and $15^{\circ} \mathrm{N}$ latitude, while in free-swimming schools bycatch was mainly located in front of Gabon. The loggerhead turtle and the leatherback turtle occurred mainly on free-swimming schools sets and their spatial distribution was similar to that observed for the Atlantic blue marlin associated with the same fishing mode. 
FADs

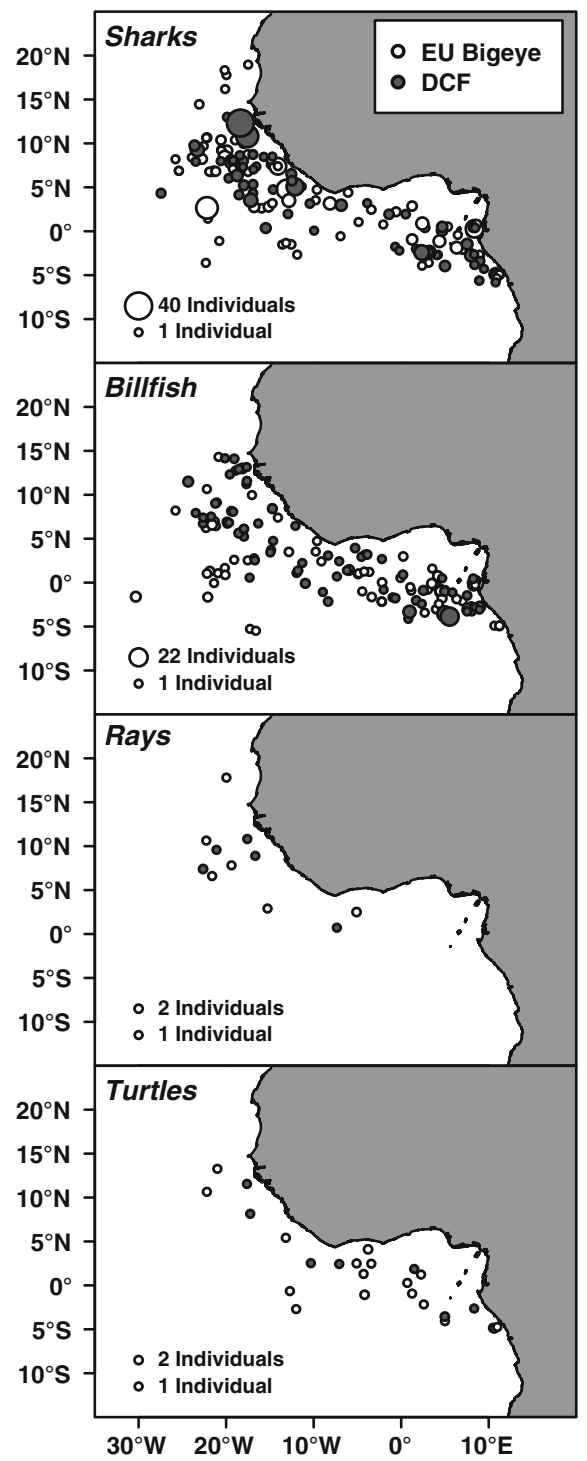

Free-swimming schools

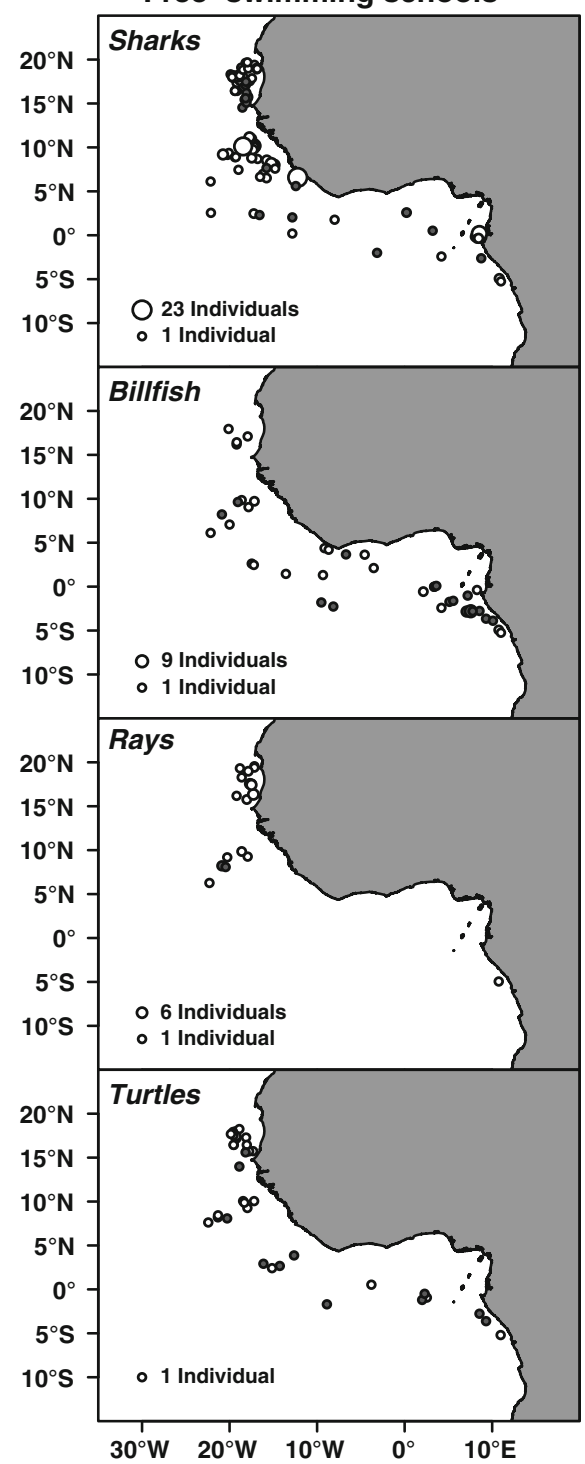

Fig. 4 Comparison of the spatial distribution of the taxonomic groups (sharks, billfishes, rays and turtles) caught incidentally during the EU Bigeye (white dots) and DCF (dark grey dots) programs by fishing mode (FADs and free-swimming schools). The number of individuals is given only as reference due to the reasons explained in Materials and methods section

\section{Discussion}

Although everybody understands what "ecosystem overfishing" means, Murawski (2000) highlighted the lack of consensus defining this term and suggested the need for objective metrics that gauge properties associated with the main features of the ecosystem (e.g., 
production, diversity, and variability). Fisheries management has been changing from a single-based regime towards an ecosystem-based fishery management (EBFM). Such approach encourages the consideration of bycatch in management in order to maintain biodiversity (Garcia et al. 2003), specifically to maintain a balanced harvesting of the ecosystem (Gaertner and Chavance 2010; Garcia et al. 2012). Due to the multispecies nature of tropical tuna purse-seine fisheries, they cannot be assessed only in terms of tuna catch (Gaertner et al. 2002). Our findings contribute to understanding the effect of the two fishing modes employed by tuna purse-seiners on the epipelagic ecosystem in the tropical Atlantic Ocean, increasing knowledge towards an EBFM. Tuna purse-seining captures a number of epipelagic species for which there is a lack of knowledge about their status and role in the ecosystem.

The effects of this fishery on bycatch species, which will be different depending on their productivity and vulnerability (Arrizabalaga et al. 2011), need to be further investigated. For instance, while low bycatch mortality may have a great impact on certain vulnerable species, such as sharks, high bycatch mortality (e.g. approximately 80-90\% of the bycatch is composed of small tuna species and other bony fishes) of other more productive groups may not affect the ecosystem, based on the balanced harvest concept (Garcia et al. 2012). In this sense, it is argued that a balanced exploitation might reduce many of the ecological effects of fishing by avoiding the intensive removal of particular components of the ecosystem (Zhou et al. 2010; Garcia et al. 2012). An alternative to encourage fishermen to be more responsible in terms of ecosystem management is to account for bycatch in the calculation of fishery agreements and to promote the consumption and valorization of species usually discarded (Gaertner and Chavance 2010).

In the eastern Atlantic Ocean, in addition to the establishment of time-area closures, ICCAT has established a number of recommendations to reduce the bycatch of sharks, billfishes and turtles. Some efforts have been made to change technological gears and fishing procedures to reduce shark bycatch in tuna fisheries (Cosandey-Godin and Morgan 2011), such as the use of deterrents, as well as bait stations, and/or the use of sounds and chemicals that could lure sharks away from FADs before setting (Kondel and Rusin 2007). Other efforts made to reduce the overall bycatch include restrictions on setting times (e.g., setting at times of the day when non-tuna species are less concentrated beneath the FAD), using multiple FADs to segregate certain species, and the use of biodegradable FADs designed to reduce the potential entanglement of bycatch species (Franco et al. 2012). Despite these efforts to reduce bycatch, the number of FADs deployed in the sea is unknown, but it is likely to increase with time.

After the dolphin-tuna problem in the eastern Pacific Ocean (EPO), the development of FAD-fishing worldwide in the early 1990s became a conservation issue for tuna purseseine fisheries. Nevertheless, fishing on free-swimming schools also generates bycatch, although to a lesser extent than observed with FADs, as well as the species composition between fishing modes differs (Amandè et al. 2011). Our findings show that except for sharks, the species composition caught by EU purse-seiners have not changed over time, despite the increasing use of FADs between the two periods considered. Using abundance instead of presence/absence would have been more appropriate to assess possible changes in species composition variability (Anderson et al. 2011), specifically if catches of certain species have been reduced. However, Hortal et al. (2006) showed that incidence-based estimators (e.g., Chao2) are accurate and less sensitive to drawbacks, such as sample coverage, patchiness of species distributions, and variability in the probability of capture. It should be noted that not all species are caught in the same magnitude and some of the species occurred only occasionally (Chassot et al. 2009; Amandè et al. 2010). In addition, 
because EU Bigeye observer program focused on the effects of FADs on bigeye tuna not all species were systematically identified at a species level, limiting further analyses using abundance and/or weight data.

With regard to the different fishing gears exploiting the high-sea ecosystem, the EU tuna purse-seiners operating in the Atlantic Ocean generate less bycatch than tuna or tuna-like species longline fisheries. For instance, sharks and billfishes bycatch by longliners targeting tuna correspond to 8.7 and $6.3 \%$ of the total catch respectively (Matsumoto and Miyabe 2000), whereas in the EU purse-seine fleet, these species groups only represent 0.09 and $0.4 \%$ of the total catch respectively (Amandè et al. 2010). The observation of fewer species of groups caught during the second period might possibly have been caused in part by changes in the spatial distribution of fishing effort. This may be biased by the small number of fishing trips observed, or due to changes in setting behavior of purseseiners related with the implementation of the moratorium on FADs, mainly avoiding schools where small-sized tuna are present (as suggested by Goujon 2004), or by real abundance decreasing (Gerrodette et al. 2012). Recently, Amandè et al. 2012 showed that increasing the sampling coverage rate will result in a reduction of bias when estimating bycatch species in tuna purse-seine fisheries in the Indian Ocean. Although the magnitude of bycatch in tropical tuna purse-seine fisheries is small, it can raise conservation issues due to the high biodiversity of species that are incidentally caught, mainly endangered and vulnerable species, such as turtles, sharks, and rays (Amandè et al. 2012). Among the species cataloged as threatened by the IUCN and caught by the EU purse-seine fleet, only Atlantic blue marlin presented high occurrences under FADs. The other species with high occurrences are not catalogued as threatened (e.g., silky shark is near threatened and the status of Atlantic sailfish is unknown). Notice that stocks of billfishes are evaluated by ICCAT, but their status remains uncertain due to the low quality of information on catch and effort of these species. It makes sense to assume that the decline in top predators may increase predators or herbivores in mid-trophic levels (mesoconsumers), thereby affecting their prey (Heithaus et al. 2008). However this assumption was not supported by the tuna purse-seine fishery operating in the EPO, where there is no evidence of decreasing trophic levels in landings and discards. The same pattern is observed when evaluating the index of replacement time of landings and discards on free-swimming schools and FADs (Gerrodette et al. 2012).

The potential problems associated with bycatch and/or discards can be extensive: threatening endangered species, wasting resources, increasing fishery costs, damaging habitat, affecting the foodweb and redirecting ecosystem pathways (Hall et al. 2000). Given sufficient investment in research and development, changes in fishing gear and methods are possible that could reduce bycatch in tuna fisheries. While recognizing that long-term viability relies on the availability of tuna resources, voluntary action by the tuna fishing industry to reverse and prevent further overexploitation of tuna stocks and to address bycatch issues may be limited (Gilman 2011). In the case of purse-seining in the Atlantic Ocean, there is a local market of "faux poisson" in Abidjan, Côte d'Ivoire, which may valorize the main component of the bycatch as a byproduct (Romagny et al. 2000). The "faux poisson" landed by the EU purse-seiners, consists of undersized skipjack and small tunas species mainly, has fluctuated since the early 1980s with a recent increasing trend, from around 8,000 $\mathrm{t}$ in 2003 to 30,000 $\mathrm{t}$ in 2009 (Chassot et al. 2009; Chavance et al. 2011). In such context, offering extra income for bycatch, fishers could be encouraged to a point where they do not entirely avoid bycatch. For this reason, it was suggested to include bycatch in the calculation of fishing agreements (Gaertner and Chavance 2010). 
While efforts to manage bycatch have been made by Regional Fisheries Management Organizations (RFMOs), several gaps remain, and compliance by many member States is likely to be low (Amandè et al. 2012). However, research is only a small part of bycatch management. Reducing bycatch to sustainable levels (e.g., promoting better selectivity, and not only focusing on greater selectivity) will also require collaborative efforts among scientists, conservation organizations, resource managers and industry. Effective tuna fisheries management will require coordinated actions by RFMOs to develop a combination of technological improvements, changes in fishing practices, modification of fishing effort and international agreements that, together, can monitor and manage bycatch, reducing the negative effects of these practices on the epipelagic ecosystem (Lewison et al. 2004). Tuna purse-seine fishery management must extend observer programs to all contracting parties to ensure that an EBFM may be implemented in practice.

Acknowledgments The observer data analyzed in this study were collected by the Institut de Recherche pour le Développement (IRD) part of the Mixed Research Unit 212 'Exploited Marine Ecosystems' (IRD/ Ifremer/U. Montpellier 2), Instituto Español de Oceanografía, and AZTI-tecnalia through the EU Research Bigeye Program (Reg 96/028) and the EU-funded Data Collection Framework (DCF, Reg (EC) 1543/2000 and 199/2008). We wish to acknowledge the contributions of ORTHONGEL, the staff of the Observatoire Thonier (IRD), and all the technicians and fishermen that have been involved in data collection, processing, and management. This study was part of the Ph.D. thesis conducted by the first author (ETI) at the University of Montpellier 2 (ED SIBAGHE) and funded by Consejo Nacional de Ciencia y Tecnología (CONACYT), Mexico, Scholarship No. 199730.

\section{References}

Alverson DL, Freeberg MH, Pope JG, Murawski SA (1994) A global assessment of fisheries bycatch and discards. FAO fisheries technical paper 339. Food and Agriculture Organization, Rome

Amandè MJ, Chassot E, Chavance P, Planet R (2008) Silky shark (Carcharhinus falciformis) bycatch in the French tuna purse-seine fishery of the Indian Ocean. In: IOTC proceedings IOTC-2008-WPEB-16 22

Amandè MJ, Ariz J, Chassot E et al (2010) Bycatch of the European purse seine tuna fishery in the Atlantic Ocean for the 2003-2007 period. Aquat Living Resour 23:353-362. doi:10.1051/alr/2011003

Amandè MJ, Ariz J, Chassot E et al (2011) By-catch and discards of the European purse seine tuna fishery in the Atlantic Ocean: estimation and characteristics for 2008 and 2009. Col Vol Sci Pap ICCAT $66: 2113-2120$

Amandè MJ, Chassot E, Chavance P et al (2012) Precision in bycatch estimates: the case of tuna purse-seine fisheries in the Indian Ocean. ICES J Mar Sci 69:1501-1510

Anderson MJ (2006) Distance-based tests for homogeneity of multivariate dispersions. Biometrics 62:245-253. doi:10.1111/j.1541-0420.2005.00440.x

Anderson MJ, Ellingsen KE, McArdle BH (2006) Multivariate dispersion as a measure of beta diversity. Ecol Lett 9:683-693. doi:10.1111/j.1461-0248.2006.00926.x

Anderson MJ, Crist TO, Chase JM et al (2011) Navigating the multiple meanings of $\beta$ diversity: a roadmap for the practicing ecologist. Ecol Lett 14:19-28. doi:10.1111/j.1461-0248.2010.01552.x

Ariz J, Gaertner D (1999) A study of the causes of the increase of the catches of bigeye tuna by the European purse seine tuna fleets in the Atlantic Ocean. Program EU DG-Fish (96/028) 70

Arrizabalaga H, de Bruyn P, Diaz GA et al (2011) Productivity and susceptibility analysis for species caught in Atlantic tuna fisheries. Aquat Living Resour 24:1-12. doi:10.1051/alr/2011007

Chao A (1984) Nonparametric estimation of the number of classes in a population. Scand J Statist $11: 265-270$

Chassot E, Amandè MJ, Chavance P et al (2009) Some preliminary results on tuna discards and bycatch in the French purse seine fishery of the eastern Atlantic Ocean. Col Vol Sci Pap ICCAT 64:1054-1067

Chavance P, Kothias JBA, Dewals P et al (2011) Statistics on tuna surface fishery's bycatch landed in Abidjan, Côte d'Ivoire, for the 1982-2009 period. Col Vol Sci Pap ICCAT 66:2104-2112

Colwell RK, Coddington JA (1994) Estimating terrestrial biodiversity through extrapolation. Phil Trans R Soc B 345:101-118 
Colwell RK, Mao CX, Chang J (2004) Interpolating, extrapolating, and comparing incidence-based species accumulation curves. Ecology 85:2717-2727

Cosandey-Godin A, Morgan A (2011) Fisheries bycatch of sharks: options for mitigation. PEW Ocean Science Division, Pew Environment Group, Washington, DC

Davies RWD, Cripps SJ, Nickson A, Porter G (2009) Defining and estimating global marine fisheries bycatch. Mar Pol 33:661-672. doi:10.1016/j.marpol.2009.01.003

Franco J, Moreno G, López J, Sancristobal I (2012) Testing new designs of drifting fish aggregating device (DFAD) in eastern Atlantic to reduce turtle and shark mortality. Col Vol Sci Pap ICCAT 68:1754-1762

Gaertner D, Chavance P (2010) Réflexion sur les grands défis scientifiques dans le domaine de la pêche thonière tropicale. J Sci Hal Aquat 1:33-38

Gaertner D, Ménard F, Develter C et al (2002) Bycatch of billfishes by the European tuna purse-seine fishery in the Atlantic Ocean. Fish Bull 100:683-689

Garcia SM, Zerbi A, Aliaume C, et al (2003) Ecosystem approach to fisheries, issues, terminology, principles, institutional foundations: implementation and outlook. FAO fisheries technical paper. no. 443. Rome, FAO

Garcia SM, Kolding J, Rice J et al (2012) Reconsidering the consequences of selective fisheries. Science 335:1045-1047. doi:10.1126/science.1214594

Gerrodette T, Olson R, Reilly S et al (2012) Ecological metrics of biomass removed by three methods of purse-seine fishing for tunas in the eastern tropical Pacific Ocean. Conserv Biol 26:248-256

Gilman EL (2011) Bycatch governance and best practice mitigation technology in global tuna fisheries. Mar Pol 35:590-609

Gilman E, Passfield K, Nakamura K (2013) Performance of regional fisheries management organizations: ecosystem-based governance of bycatch and discards. Fish Fish. doi:10.1111/faf.12021

Gotelli NJ, Colwell RK (2001) Quantifying biodiversity: procedures and pitfalls in the measurement and comparison of species richness. Ecol Lett 4:379-391

Goujon M (2004) Informations sur l'activité des thoniers senneurs et du supply français et sur les observations en mer d'après les données collectées pendant les plans de protection des thonidés de l'Atlantique 2000-2001, 2001-2002 et 2002-2003. Col Vol Sci Pap ICCAT 56:432-442

Hall MA (1996) On bycatches. Rev Fish Biol Fish 6:319-352. doi:10.1007/BF00122585

Hall SJ, Mainprize BM (2005) Managing by-catch and discards: how much progress are we making and how can we do better? Fish Fish 6:134-155. doi:10.1111/j.1467-2979.2005.00183.x

Hall MA, Alverson DL, Metuzals KI (2000) By-catch: problems and Solutions. Mar Pollut Bull 41:204-219. doi:10.1016/S0025-326X(00)00111-9

Heithaus MR, Frid A, Wirsing AJ, Worm B (2008) Predicting ecological consequences of marine top predator declines. Trends Ecol Evol 23:202

Hortal J, Borges PAV, Gaspar C (2006) Evaluating the performance of species richness estimators: sensitivity to sample grain size. J Anim Ecol 75:274-287. doi:10.1111/j.1365-2656.2006.01048.x

Kondel J, Rusin J (2007) Report of the 2nd Workshop on bycatch reduction in the ETP purse-seine fishery. National Marine Fisheries Service, SWFSC 60, La Jolla, CA

Lewison R, Crowder L, Read A, Freeman S (2004) Understanding impacts of fisheries bycatch on marine megafauna. Trends Ecol Evol 19:598-604. doi:10.1016/j.tree.2004.09.004

Matsumoto T, Miyabe N (2000) Report of 1999 observer progam for Japanese tuna longline fishery in the Atlantic Ocean. Col Vol Sci Pap ICCAT 51:729-749

Murawski SA (2000) Definitions of overfishing from an ecosystem perspective. ICES J Mar Sci 57:649-658

Pallarés P, Petit C (1998) Tropical tunas: new sampling and data processing strategy for estimating the composition of catches by species and sizes. Col Vol Sci Pap ICCAT 48:230-246

Pianet R, Delgado A, Floch L et al (2011) Statistiques de la pêcherie thonière européenne et assimilée durant la période 1991-2010. Col Vol Sci Pap ICCAT 68:886-914

Romagny B, Ménard F, Dewals P, et al. (2000) Le "faux-poisson" d'Abidjan et la pêche sous DCP dérivants dans l'Atlantique tropical Est: circuit de commercialisation et rôle socio-économique. In: Le Gall J-Y, Cayré $\mathrm{P}$, Taquet $\mathrm{M}$ (eds) Le Pêche thonière et dispositifs de concentration de poissons. Ifremer, pp 634-652

Terlizzi A, Anderson MJ, Bevilacqua S et al (2009) Beta diversity and taxonomic sufficiency: do higherlevel taxa reflect heterogeneity in species composition? Divers Distrib 15:450-458. doi:10.1111/j. 1472-4642.2008.00551.x

Zhou S, Smith ADM, Punt AE et al (2010) Ecosystem-based fisheries management requires a change to the selective fishing philosophy. Proc Natl Acad Sci USA 107:9485-9489. doi:10.1073/pnas.0912771107 